\title{
Shape of the mandible in European bison and domestic cattle hybrids
}

\author{
Franciszek KOBRYŃCZUK and Małgorzata KRASIŃSKA
}

\begin{abstract}
Kobryńczuk F. and Krasińska M. 1991. Shape of the mandible in European bison and domestic cattle hybrids. Acta theriol. 36: $171-177$.

The shape of the mandible of European bison and domestic cattle hybrids and the parental forms was compared by means of a discriminant function. In most cases it was observed that the mandibles of hybrids of backcross generations are similar or identical to cattle. Exceptions were found in $F_{1}$ hybrids and some backcross generations whose mandibles were more similar to bison than to cattle. The transformation of the mandible shape in hybrids with increasing cattle genes is similar to changes in the skull shape of the same animals.
\end{abstract}

Department of Animal Anatomy, Warsaw Agricultural University, Nowoursynowska 166, 02-766 Warsaw, Poland (FK); Mammal Research Institute, Polish Academy of Sciences, 17-230 Białowieża, Poland (MK)

Key words: mandible shape, European bison, cattle, bison $\times$ cattle hybrids

\section{Introduction}

This work is a continuation of research dealing with similarities in the bones of hybrids of European bison Bison bonasus (Linnaeus, 1758) and domestic cattle Bos taurus Linnaeus, 1758 as well as parental forms. Previously it was ascertained that when the European bison blood diminishes the skulls of hybrids become more similar to cattle skulls (Kobryńczuk and Krasińska 1987).

The subject of this research was the mandible bone. It was excluded from earlier observations due to the large variances in its parameters and the greater influence the chewing muscles have on its shape than on the skull. Mandible is also more mobile and has a different development.

\section{Material and methods}

The material included 43 European bison, 31 domestic cattle and 55 hybrids of these species (Tables 1 and 3). The percentage of the European bison blood in backcross generations diminished from $25.0 \%$ to $6.25 \%$. Bison age was established on the basis of the Pedigree Book of the European bison (Żabiński 1947 - 63, Żabiński and Raczyński 1972). The age of hybrids was known from their pedigree and that of cattle was determined on the skull fissures.

$F_{1}$ hybrids have originated from crossing both sexes of the European bison with domestic cattle. The hybrids of backcross generations $\mathrm{B}_{1}$ bos, $\mathrm{B}_{2}$ bos and $\mathrm{B}_{3}$ bos were obtained by mating of female hybrids of different generations with domestic bulls. The red Polish breed (rp) and black-white lowland breed (bwl) of cattle were used. Exact information about the animals used for mating can be found in earlier reports (Kobryńczuk and Krasińska 1987, Krasińska 1988). 
The right and left mandibles were measured as exact as to a millimetre. For further analysis means of both measurements were used. Using the method of Duerst (1926) and following the recommendations of Empel (1962) the following five measurements were made (Fig.1):

(1) id-goc - Infradentale-Gonion caudale,

(2) id-gov - Infradentale-Gonion ventrale (in projection),

(3) HCM - The height of corpus mandibulae behind $\mathrm{M}_{3}$,

(4) gov-cm - Gonion ventrale-Coronion mediale,

(5) BRM - The breadth of ramus mandibulae.

Three indices were calculated: $\mathrm{x}_{1}-$ the height of the mandible body, $\mathrm{x}_{2}-$ the ramus width, and $\mathrm{x}_{3}-$ mandible height as follows:
$\mathrm{x}_{1}=\frac{100 \mathrm{HCM}}{\mathrm{id}-\mathrm{goc}}$
$\mathrm{x}_{2}=\frac{100 \mathrm{BRM}}{\text { goc-cm }}$
$\mathrm{x}_{3}=\frac{100 \mathrm{id}-\mathrm{gov}}{\mathrm{gov}-\mathrm{cm}}$

The mean values and observed ranges of these indices for particular groups of animals are presented in Table 1.

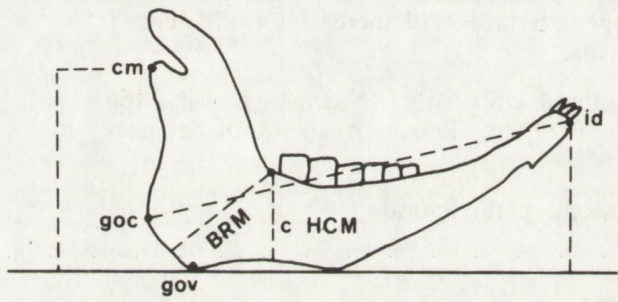

Fig. 1. Measurement points on mandible. See text for the definitions.

The individual indices for the mandibles of cattle and the European bison were used to calculate the discriminant function (Fischer 1936) which divides the bones according to species. Indices $\mathrm{x}_{1}, \mathrm{x}_{2}$ and $\mathrm{x}_{3}$ of the hybrid mandibles were subordinated to this function. Table 2 gives approximate values of mandible discriminant coefficients $\left(\mathrm{z}_{\mathrm{m}}\right)$. In Table 3 there are discriminant coefficients of the mandible of individual hybrids. Beside this the discriminant coefficients for skulls $\left(z_{c}\right)$ taken from a previous study (Kobryńczuk and Krasińska 1987) are presented.

Hybrid material comes from the collection of the Mammal Research Institute, Polish Academy of Sciences in Białowieża. Bison and cattle come from the Department of Animal Anatomy, Agricultural Academy in Warsaw.

\section{Results}

The discriminant function dividing cattle and bison mandibles had the following form:

$$
\begin{aligned}
& \text { for males: } \mathrm{z}_{\mathrm{m}}=-14.56 \mathrm{x}_{1}+1.66 \mathrm{x}_{2}-0.44 \mathrm{x}_{3}+195.00 \\
& \text { for females: } \mathrm{z}_{\mathrm{m}}=-2.31 \mathrm{x}_{1}-0.16 \mathrm{x}_{2}-0.05 \mathrm{x}_{3}+58.00
\end{aligned}
$$

This function completely separated cattle and the European bison mandibles marking the former as negative and latter as positive discriminant coefficients (Table 2).

In mandibles of male cattle the discriminant coefficient ranges from -61.5 to -37.5 , and of male European bison, from +37.5 to +88.8 . The difference between the largest discriminant coefficient in cattle and the smallest in European bison was 75. This difference was referred to as the interspecies demarcation zone (Kobryńczuk and Krasińska 1987).The value of this zone for skulls of cattle and bison was 38. One can conclude from this that the skulls of male cattle and bison were more similar in respect of their shape than their mandibles. 
In females of the cattle the discriminant coefficient for mandibles ranges from -12.1 (bwl) to -0.58 (rp) and in females of the European bison from +0.66 to +7.5 (Table 2). The demarcation zone in this case is only 1.24 of discriminant coefficient units. The corresponding zone for female skulls for both species was 4.3 . Thus one can conclude that - on the contrary

Table 1. Variation in mandible coefficients. $\mathrm{x}_{1}, \mathrm{x}_{2}$, and $\mathrm{x}_{3}$ are defined in the text. Abbreviations: bwl - black and white lowland breed; $\mathrm{rp}$ - red Polish breed; $\mathrm{B}_{1}$ bos $-25 \%$ European bison, $75 \%$ cattle; $\mathrm{B}_{2}$ bos $-12.5 \%$ European bison, $87.5 \%$ cattle; B bos $-6.25 \%$ European bison, $93.75 \%$ cattle.

\begin{tabular}{|c|c|c|c|c|c|c|}
\hline \multirow[b]{2}{*}{ Species } & \multirow{2}{*}{$\begin{array}{l}\text { Breed } \\
\text { gener- } \\
\text { ation }\end{array}$} & \multirow[b]{2}{*}{$\mathrm{n}$} & \multirow{2}{*}{$\begin{array}{c}\text { Average } \\
\text { age } \\
\min -\max \end{array}$} & \multicolumn{3}{|c|}{ Coefficients } \\
\hline & & & & $\begin{array}{c}\bar{x}_{1} \\
\min -\max \end{array}$ & $\begin{array}{c}\bar{x}_{2} \\
\min -\max \end{array}$ & $\begin{array}{c}\bar{x}_{3} \\
\min -\max \end{array}$ \\
\hline & & & Males & & & \\
\hline Bison bonasus & & 22 & $\begin{array}{c}11.2 \\
4.8-18.4\end{array}$ & $\begin{array}{c}15.0 \\
14-16\end{array}$ & $\begin{array}{c}77.3 \\
64-88\end{array}$ & $\begin{array}{c}89.0 \\
77-99\end{array}$ \\
\hline Bos taurus & bwl & 4 & adults & $\begin{array}{c}22.0 \\
22-23\end{array}$ & $\begin{array}{c}72.0 \\
63-78\end{array}$ & $\begin{array}{c}97.0 \\
74-147\end{array}$ \\
\hline \multirow[t]{5}{*}{ Hybrids } & $F_{1}$ & 5 & $\begin{array}{c}8.8 \\
5.2-13.0\end{array}$ & $\begin{array}{c}18.4 \\
16-20\end{array}$ & $\begin{array}{c}79.8 \\
72-86\end{array}$ & $\begin{array}{c}88.2 \\
77-96\end{array}$ \\
\hline & $\mathrm{B}_{1}$ bos & 13 & $\begin{array}{c}3.3 \\
0.5-7.0\end{array}$ & $\begin{array}{c}20.6 \\
19-22\end{array}$ & $\begin{array}{c}68.8 \\
55-78\end{array}$ & $\begin{array}{c}86.8 \\
64-115\end{array}$ \\
\hline & $\mathrm{B}_{2}$ bos & 7 & $\begin{array}{c}3.8 \\
0.4-4.4\end{array}$ & $\begin{array}{c}21.0 \\
18-23\end{array}$ & $\begin{array}{c}67.0 \\
60-73\end{array}$ & $\begin{array}{c}87.1 \\
55-101\end{array}$ \\
\hline & $\mathrm{B}_{3}$ bos & 1 & 2.0 & 21.0 & 74.0 & 120.0 \\
\hline & & & Females & & & \\
\hline Bison bonasus & & 21 & $\begin{array}{c}11.2 \\
2.0-19.8\end{array}$ & $\begin{array}{c}15.5 \\
13-18\end{array}$ & $\begin{array}{c}78.2 \\
52-101\end{array}$ & $\begin{array}{c}91.8 \\
67-111\end{array}$ \\
\hline \multirow[t]{2}{*}{ Bos taurus } & $\mathrm{rp}$ & 14 & adults & $\begin{array}{c}20.1 \\
19-21\end{array}$ & $\begin{array}{c}73.1 \\
67-80\end{array}$ & $\begin{array}{c}84.2 \\
73-94\end{array}$ \\
\hline & bwl & 13 & adults & $\begin{array}{c}21.9 \\
20-24\end{array}$ & $\begin{array}{c}67.8 \\
62-74\end{array}$ & $\begin{array}{c}76.2 \\
73-89\end{array}$ \\
\hline \multirow[t]{4}{*}{ Hybrids } & $\mathrm{F}_{1}$ & 2 & $\begin{array}{c}7.5 \\
7.8-8.0\end{array}$ & $\begin{array}{c}18.5 \\
18-19\end{array}$ & $\begin{array}{c}66.5 \\
64-69\end{array}$ & $\begin{array}{c}83.0 \\
72-94\end{array}$ \\
\hline & $\mathrm{B}_{1}$ bos & 12 & $\begin{array}{c}3.8 \\
0.5-8.0\end{array}$ & $\begin{array}{c}20.8 \\
18-24\end{array}$ & $\begin{array}{c}67.3 \\
59-77\end{array}$ & $\begin{array}{c}86.8 \\
68-116\end{array}$ \\
\hline & $\mathrm{B}_{2}$ bos & 11 & $\begin{array}{c}3.5 \\
0.6-5.4\end{array}$ & $\begin{array}{c}20.1 \\
19-23\end{array}$ & $\begin{array}{c}67.0 \\
58-74\end{array}$ & $\begin{array}{c}87.2 \\
69-115\end{array}$ \\
\hline & $\mathrm{B}_{3}$ bos & 4 & $\begin{array}{c}0.5 \\
1.0-2.2\end{array}$ & $\begin{array}{c}21.8 \\
21-22\end{array}$ & $\begin{array}{c}72.8 \\
59-81\end{array}$ & $\begin{array}{c}84.0 \\
66-95\end{array}$ \\
\hline
\end{tabular}


Table 2. Numerical distribution of mandibular bones on the basis of their discriminant power.

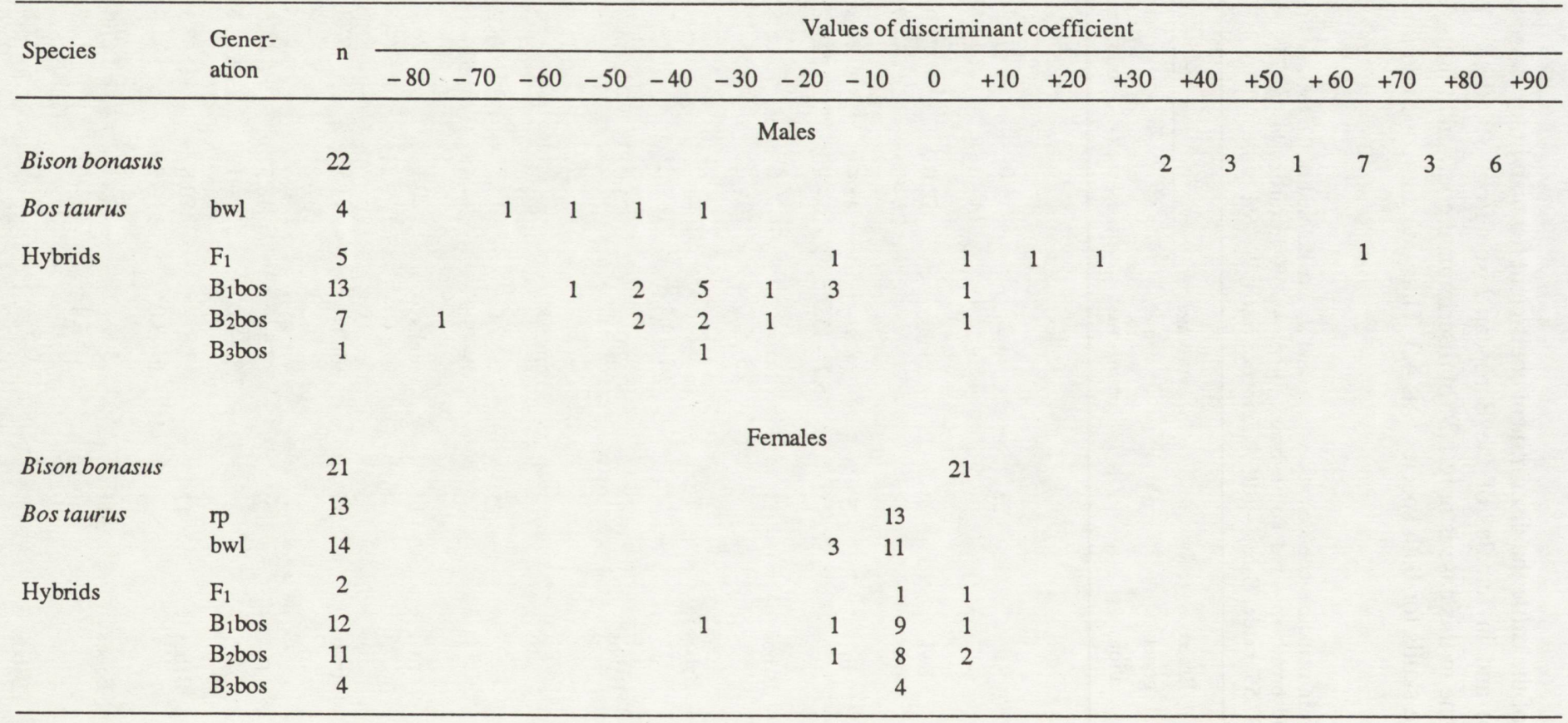


to what was found in males - the mandibles of female cattle and bison were more similar than their skulls.

Substituiting into both discriminant functions the mandible indices of hybrids, in most cases a negative discriminant coefficients were obtained, indicating the presence of cattle traits in these bones (Table 3). Exceptions were also noted. Of five males from the $F_{1}$ generation, only one (Farad) had a negative discriminant coefficient $(-14.0)$, but it was not as low as in cattle.

Table 3. Discriminant coefficiennt of mandible $\left(\mathrm{z}_{\mathrm{m}}\right)$ and skull $\left(\mathrm{z}_{\mathrm{c}}\right)$ in hybrids.

\begin{tabular}{|c|c|c|c|c|c|c|c|c|}
\hline \multirow[b]{2}{*}{$\begin{array}{l}\text { Gener- } \\
\text { ation }\end{array}$} & \multicolumn{4}{|c|}{ Males } & \multicolumn{4}{|c|}{ Females } \\
\hline & Name & $\begin{array}{l}\text { Age } \\
\text { yrs }\end{array}$ & $\mathrm{z}_{\mathrm{m}}$ & $\mathrm{z}_{\mathrm{c}}$ & Name & $\begin{array}{l}\text { Age } \\
\text { yrs }\end{array}$ & $\mathrm{z}_{\mathrm{m}}$ & $z_{c}$ \\
\hline \multirow[t]{5}{*}{$\mathrm{F}_{1}$} & 1. Fakir & 3.2 & +64.4 & -8.2 & 1. Filutka & 7.0 & +1.5 & +0.6 \\
\hline & 2. Farad & 6.4 & -14.0 & -6.9 & 2. Fama & 8.0 & -0.5 & -1.0 \\
\hline & 3. Filip & 8.0 & +9.2 & -2.1 & & & & \\
\hline & 4. Facet & 11.3 & +27.3 & -0.5 & & & & \\
\hline & 5. Filon & 13.0 & +19.4 & -9.0 & & & & \\
\hline \multirow[t]{13}{*}{$\mathrm{B}_{1}$ bos } & 6. Fest & 0.5 & -35.4 & -7.9 & 3. Feeria & 0.5 & -10.6 & +1.5 \\
\hline & 7. Felon & 0.5 & -34.1 & -12.7 & 4. Ferina & 0.7 & -32.2 & -3.6 \\
\hline & 8. Feld & 1.5 & -54.0 & -12.3 & 5. Felly & 1.2 & -6.8 & 0.0 \\
\hline & 9. Fellach & 2.0 & -42.9 & -7.9 & 6. Ferma & 1.4 & -6.0 & -3.9 \\
\hline & 10. Festyn & 2.0 & -45.2 & -9.7 & 7. Fema & 2.3 & -10.9 & -5.3 \\
\hline & 11. Fag & 3.4 & -26.6 & -16.8 & 8. Feta & 3.2 & -5.8 & -2.4 \\
\hline & 12. Fen & 3.6 & -32.6 & -16.8 & 9. Felpa & 4.4 & -1.4 & -3.1 \\
\hline & 13. Feb & 3.6 & -17.9 & -4.8 & 10. Feska & 4.5 & -2.2 & -2.8 \\
\hline & 14. Fey & 4.1 & -30.3 & -16.5 & 11. Fewa & 5.5 & -5.9 & -4.1 \\
\hline & 15. Fez & 4.3 & -10.6 & -8.8 & 12. Fera & 6.5 & +1.3 & -5.2 \\
\hline & 16. Fetysz & 4.4 & +4.8 & -10.8 & 13. Femina & 7.5 & -2.0 & -1.2 \\
\hline & 17. Fenix & 5.5 & -14.0 & -13.7 & 14. Fenny & 8.0 & -1.5 & -4.8 \\
\hline & 18. Fell & 7.0 & -34.1 & -11.3 & & & & \\
\hline \multirow[t]{11}{*}{$\mathrm{B}_{2}$ bos } & 19. b.n. & 0 & -38.4 & & 15. Fena & 0.6 & -3.3 & -7.0 \\
\hline & 20. Feston & 0.4 & -23.2 & -11.6 & 16. Fela & 2.5 & -1.7 & -0.2 \\
\hline & 21. Fenek & 1.3 & -70.9 & -19.4 & 17. Fetwa & 2.8 & +1.8 & -4.1 \\
\hline & 22. Fenyl & 2.4 & -40.8 & & 18. Felga & 3.2 & +0.7 & -1.6 \\
\hline & 23. Fenomen & 4.2 & -48.9 & -13.4 & 19. Fenicja & 3.4 & -11.5 & -2.6 \\
\hline & 24. Fen II & 4.3 & -38.2 & -14.8 & 20. Fedela & 3.4 & -1.8 & -1.1 \\
\hline & 25. Fenol & 4.4 & +4.9 & -18.7 & 21. Ferajna & 4.2 & -3.1 & -3.1 \\
\hline & & & & & 22. Fela II & 4.3 & -1.9 & -2.6 \\
\hline & & & & & 23. Fega & 4.4 & -2.5 & -6.0 \\
\hline & & & & & 24. Ferara & 4.7 & -2.9 & -7.8 \\
\hline & & & & & 25. Festa & 5.4 & -3.3 & -1.5 \\
\hline \multirow[t]{4}{*}{$\mathrm{B}_{3}$ bos } & 26. Feliks & 2.0 & -40.2 & -13.8 & 26. Felba & 1.0 & -9.9 & -3.2 \\
\hline & & & & & 27. Fedra & 1.0 & -9.8 & -2.8 \\
\hline & & & & & 28. Ferta & 1.3 & -7.1 & -3.0 \\
\hline & & & & & 29. Feda & 2.2 & -5.5 & -3.5 \\
\hline
\end{tabular}


Therefore its' mandible was not identical in shape but only similar to that of cattle. The mandibles of three other $F_{1}$ bulls were similar to bison mandibles, but not identical $\left(\mathrm{z}_{\mathrm{m}}\right.$ is from +9.2 to +27.3 , Table 3 ). Only Fakir from $F_{1}$ generation with $\mathrm{z}_{\mathrm{m}}$ coefficient of +64.4 had a mandible shaped like that of bison.

The discriminant coefficient for skulls $\left(\mathrm{z}_{\mathrm{c}}\right)$ of male hybrids from $\mathrm{F}_{1}$ generation (Table 3 ) were negative. However the skulls of these animals were only similar and not identical to cattle skulls. Facet is an exception, with its craniometric traits intermediate for cattle and bison.

When analyzing in a similar way the shape of mandibles of two females from the $F_{1}$ generation - Filutka and Fama, one must be aware of the narrow zone of demarcation for this bone in females of the parental forms. Also with this regard Filutka had a mandible identical with bison $\left(\mathrm{z}_{\mathrm{m}}=+1.5\right.$, Table 3$)$ and Fama - identical with cattle $\left(\mathrm{z}_{\mathrm{m}}=-0.5\right)$. Similar tendencies were observed in the skull of both these females.

In the mandible of hybrid males of backcross generations ( $\mathrm{B}_{1}$ bos $-\mathrm{B}_{3}$ bos) the similarity to cattle mandibles increases. However this process is not significantly correlated with the increas of cattle blood $(r=-0.230, \mathrm{n}=21)$.

By analyzing the $\mathrm{z}_{\mathrm{m}}$ coefficient for males of backcross generation we have noted thet mandibles identical with cattle occur in four $\mathrm{B}_{1}$ bos males, four $\mathrm{B}_{2}$ bos and one $\mathrm{B}_{3}$ bos $\left(\mathrm{z}_{\mathrm{m}}\right.$ from - 70.9 to -32.6 , Table 3). Mandibles, similar in shape to cattle, were found in eight more bulls of $\mathrm{B}_{1}$ bos generation and two $\mathrm{B}_{2}$ bos. Of the discussed males from backcross generation only two animals had mandibles similar in shape to bison mandibles ( $B_{1}$ bos $\mathrm{z}_{\mathrm{m}}=+4.8$ and $\mathrm{B}_{2}$ bos $\mathrm{z}_{\mathrm{m}}=+4.9$, Table 3 ).

The mean discriminant coefficients $\mathrm{z}_{\mathrm{m}}$ for hybrid females of backcross generations ( $\mathrm{B}_{1}$ bos - B3bos) were respectively: $-6.7,-2.7$ and -8.1 . It can be concluded that female mandibles of the $\mathrm{B}_{1}$ bos generations are more similar to those bones of cattle than in the $\mathrm{B}_{2}$ bos generation in which incidentally two females were found having mandibles identical to bison (Fewa $\mathrm{z}_{\mathrm{m}}$ $=+1.8$, Felga $z_{m}=+0.7$, Table 3 ). Therefore the shape-return of the mandible of female hybrids of three generations taken together to the shape characteristic for cattle is not correlated with the increase of cattle blood as this process - intensive in $\mathrm{B}_{1}$ bos and $\mathrm{B}_{3}$ bos generations is decreased in the $\mathrm{B}_{2}$ bos generation.

Comparing the skull $\left(\mathrm{z}_{\mathrm{c}}\right)$ discriminant coefficient of male hybrids of backcross generations (Table 3) it can be stated that mandibles of these animals to a greater extent than skulls inherit cattle traits. A similar analysis dealing with females of these generations is difficult due to the narrow zone of demarcation. It therefore can be assumed that back-transition of the mandible and skull shapes in females of backcross generation to the form characteristic for cattle is advanced to the same degree.

\section{Discussion}

An analysis of skull and mandible shape of European bison with domestic cattle shows that ancestral traits located in these parts of skeleton do not always follow the genetic law of Galton, according to which individual receives from each parent approximately half its genetic material. An example of the lack of subordination to this law can be the mandibles of $F_{1}$ bull - Fakir and $F_{1}$ cow - Filutka, which were identical to bison in respect of their shape. Further- 
more the mandibles of some hybrids of backcross forms (Fetysz, Fenol, Fera, Fetwa, Felga) showed mandible traits of bison, and not cattle, as it should be. There are more such disagreements with the law of quantitative genetics in the inheritance of ancestral traits in the mandible than in the skull. The reason for this was certainly the fact that the mandible is a flat bone, while the skull is a solid figure. Hence the growth vectors of skull bones are to a greater degree multi-directional than mandibles ones. The effect of this is a greater variation in mandible parameters than in the skull, as well as negative correlation between some parameters of these two parts of the head skeleton (Kobryńczuk and Roskosz 1980).

The material, heterogenous in respect of age, makes it possible to treat age as an independent variable shaping the mandible after birth. Evidence of this is the significant correlation between age and the discriminant coefficient in the $\mathrm{B}_{1}$ bos generation. For males the coefficient of this correlation is $r=+0.514$, and for females $r=+0.646$ (in both instances $p<0.05$ ). Considering this as a basis it is possible to conclude tentatively that the similarity of the hybrid and parental species mandibles changes with age. The mandibles of young $\mathrm{B}_{1}$ bos animals were more similar to cattle bones than those of adult animals. Similarly, no significant correlation between age and the discriminant coefficient has been found in skulls of the same generation.

Analysing the structure of both discriminant functions, it can be stated that the most important traits for cattle and the European bison mandibles is the coefficient $\mathrm{x}_{1}$, with the largest absolute value. It was greater in males than in females. This difference, expressing the size of the demarcation zone for mandibles, is significantly larger in males than in females of cattle and bison. Therefore the transition of the bone shape in hybrids from the form typical for bison to what is characteristic for cattle is faster in females than in males. The value of coefficient $\mathrm{x}_{1}$ depends first of all on the hight of the mandible body so this metrical trait is the best feature for differentiating cattle and bison mandibles as well as the most useful taxonomic trait for describing similarities of these bones in relation to its shape in parental species.

\section{References}

Duerst J. U. 1926. Vergleichende Untersuchungsmethoden am Skelett bei Säugern. Urban und Schwarzenberg, Berlin - Vien: $125-530$.

Empel W. 1962. Morphologie des Schädels von Bison bonasus (Linnaeus, 1758). Acta theriol. 6: 53 - 111.

Fisher R. A. 1936. The use of multiple measurement in taxonomic problems. Annals Eug. 7: 179-188.

Kobryńczuk F. and Krasińska M. 1987. Taxonomic studies on skull of European bison and domestic cattle hybrids. Acta theriol. 32: $203-218$.

Kobryńczuk F. and Roskosz T. 1980. Correlations of skull dimensions in the European bison. Acta theriol. 25: $349-363$.

Krasińska M. 1988. Variability of the skull shape in hybrids between European bison and domestic cattle. Acta theriol. 32: $147-186$.

Żabiński J., (ed.). 1947 - 63. Pedigree book of the European bison. Państw. Wyd. Nauk. Warszawa: 1 - 370.

Żabiński J. and Raczyński J., (eds). 1972. European bison pedigree book 1965 - 69. Państw. Wyd. Nauk. Warszawa: $1-78$. 